\title{
Invading the Adriatic: spatial patterns of marine alien species across the Ionian-Adriatic boundary
}

\author{
Stelios Katsanevakis ${ }^{1, *}$, Argyro Zenetos ${ }^{1}$, Vesna Mačić ${ }^{2}$, Sajmir Beqiraj ${ }^{3}$, \\ Dimitrios Poursanidis ${ }^{4,5}$, Lefter Kashta ${ }^{6}$ \\ ${ }^{1}$ Institute of Marine Biological Resources, Hellenic Centre for Marine Research, Anavyssos 19013, Greece \\ ${ }^{2}$ Institute of Marine Biology, Kotor, Montenegro \\ ${ }^{3}$ Biology Department, Faculty of Natural Sciences, University of Tirana, Bulevardi Zog I, Tirana, Albania \\ ${ }^{4}$ WWF Hellas, Knossos, Heraklion, Crete, Greece \\ ${ }^{5}$ Department of Marine Sciences, University of the Aegean, Mytilene 81100, Greece \\ ${ }^{6}$ Research Center for Flora and Fauna, Faculty of Natural Sciences, University of Tirana, Bulevardi Zog I, Tirana, Albania
}

\begin{abstract}
An important pathway of introduction of alien marine species in the Adriatic seems to be the northward expansion of species already established in the Ionian Sea, aided by the East Adriatic Current. We modelled the occupancy of alien marine species in the upper infralittoral zone of rocky bottoms across the Ionian-Adriatic border (Albanian and Montenegrin coastlines), based on underwater visual survey data. A method that took into account imperfect detection of the target species was applied to make unbiased occupancy estimations, based on a multi-model inference approach. A total of 6 alien species were found during the survey (in decreasing order of occupancy): Caulerpa racemosa, Percnon gibbesi, Ganonema farinosum, Lophocladia lallemandii, Asparagopsis taxiformis and Pinctada radiata. There was a general pattern of declining occupancy from northern Ionian Albanian coastal waters towards the southeastern Adriatic coastline. Possible reasons for this pattern are: (1) the invasion of some species from the northern Ionian Sea is still in progress and the limit of the current distributional range falls within or near the study area; (2) the lower temperatures in the Adriatic Sea restrict the northward expansion of thermophilic alien species; and (3) the part of Albania north of the Otranto Strait is characterized by sandy/muddy coasts, large estuarine areas and substantial freshwater input, creating a barrier for expansion of sessile species. There is a pool of 77 species established in the central Mediterranean but not yet observed in the Adriatic Sea. Among these, 14 species are present in the Greek Ionian Sea and may be considered as the most probable newcomers to the Adriatic Sea in the near future.
\end{abstract}

KEY WORDS: Alien · Biological invasion · Occupancy · Detectability · Adriatic Sea $\cdot$ Ionian Sea • Albania $\cdot$ Montenegro

\section{INTRODUCTION}

The Mediterranean Sea is a region undergoing massive changes in its marine biota, as it is severely affected by biological invasions (Zenetos 2009, Por 2010). Such changes were brought about mainly due to a combination of general warming of the Mediterranean Sea and the opening of the Suez Canal in 1869, which established the connection of the eastern Mediterranean with the Indo-Pacific realm (Por 2010, Raitsos et al. 2010). Fouling and ballast water transportation along shipping lines, aquaculture and the aquarium trade are also blamed for many alien invasions. Nearly 1000 alien marine species have been recorded in the Mediterranean up to now and their number keeps increasing, with a rate of one new record every $1.5 \mathrm{wk}$ (Zenetos 2010). Among the recorded alien marine species, 535 species (56\%) are established in at least one area, with 134 species exhibiting aggressive invasive behaviour, leading to alterations in ecosystem function- 
ing, biodiversity loss and negative effects on human activities such as fisheries, tourism and aquaculture (Zenetos et al. 2010). The reported marine alien species in the Mediterranean Sea represent approximately $6 \%$ of the known biodiversity, which is estimated at approximately 17000 species (Coll et al. 2010). However, this percentage is higher for certain taxa, e.g. in fish it reaches $28 \%$ (149 introduced vs. 534 native) (Zenetos et al. 2010). As most of these species are of tropical affinity and origin, their high incidence is driving the Mediterranean biota towards a phase of 'tropicalization' (Bianchi \& Morri 2003).

Of the 955 alien species known in the Mediterranean, the vast majority have been observed in the eastern Mediterranean (718), fewer have been observed in the central Mediterranean, including the Ionian Sea (268), and the fewest (171) have been observed in the Adriatic (Zenetos et al. 2010).

The Adriatic Sea is a rather unique and differentiated area within the Mediterranean, with a strong contrast between the predominantly linear sandy shores along the western (Italian) side, and the complex coasts of the eastern side (Slovenia, Croatia, Montenegro and Albania) forming a maze of islands and inlets with rocky shores. The hydrographical conditions are also peculiar, with very low winter temperatures in the northern part, which is also quite shallow (40 m depth), and very hot summers in the southern part, which is much deeper. All these features lead to a biogeographic differentiation of the Adriatic to 3 sectors arranged more or less latitudinally (northern, middle and southern) (Bianchi et al. 2011).

The northern Adriatic coasts are the most affected by alien invasions, probably because of a flood of introductions along with shellfish transfers (oysters, mussels and Manila clams) on the north Italian coasts, where aquaculture is extensively developed. However, an important pathway of introduction of alien marine species in the Adriatic seems to be the northward expansion of species already established in the Ionian Sea.

The aim of this study was to assess the occupancy patterns of alien marine species across the IonianAdriatic border and investigate the presence and establishment success of potential alien invaders. To reach unbiased occupancy estimations, a methodology that accounted for imperfect detectability of the target species was followed. Based on the distribution of established alien species in the neighbouring area (central Mediterranean Sea and Ionian Sea), a list of potential invaders is presented as a risk assessment tool. Such information will increase our understanding of the invasion patterns of alien marine species in the Adriatic Sea, and will be useful in future evaluations of invasion rates and impact assessments.

\section{MATERIALS AND METHODS}

Study area. The study area included the coastlines of Albania and Montenegro (Fig. 1). The southern Adriatic-northern Ionian system has a key role in the functioning of the entire Mediterranean basin by the formation of dense $\mathrm{O}_{2}$-rich water that flows into the Ionian basin, oxygenating the deep waters of the eastern Mediterranean (Manca et al. 2002). The southern Adriatic is characterized by a wide depression more than 1200 m deep (the South Adriatic Pit). The water exchange with the Mediterranean Sea takes place through the $75 \mathrm{~km}$ wide Strait of Otranto, whose sill is $800 \mathrm{~m}$ deep. Ionian surface waters typically enter the Adriatic close to the Albanian side (East Adriatic Current) and flow out along the Italian side (West Adriatic Current) according to a permanent cyclonic circulation regime (Artegiani et al. 1997, Falco et al. 2000). The main hydrological pattern of surface waters moving northwards along the Albanian and Montenegrin coastline ensures the possibility of transfer of biological material from the northeastern Ionian Sea to the southeastern Adriatic Sea. The southern Albanian and the Montenegrin coastlines are generally rocky, whereas the part of Albania north of the Otranto Strait is characterized by sandy/muddy coasts with only few short segments of hard bottoms, large estuarine areas

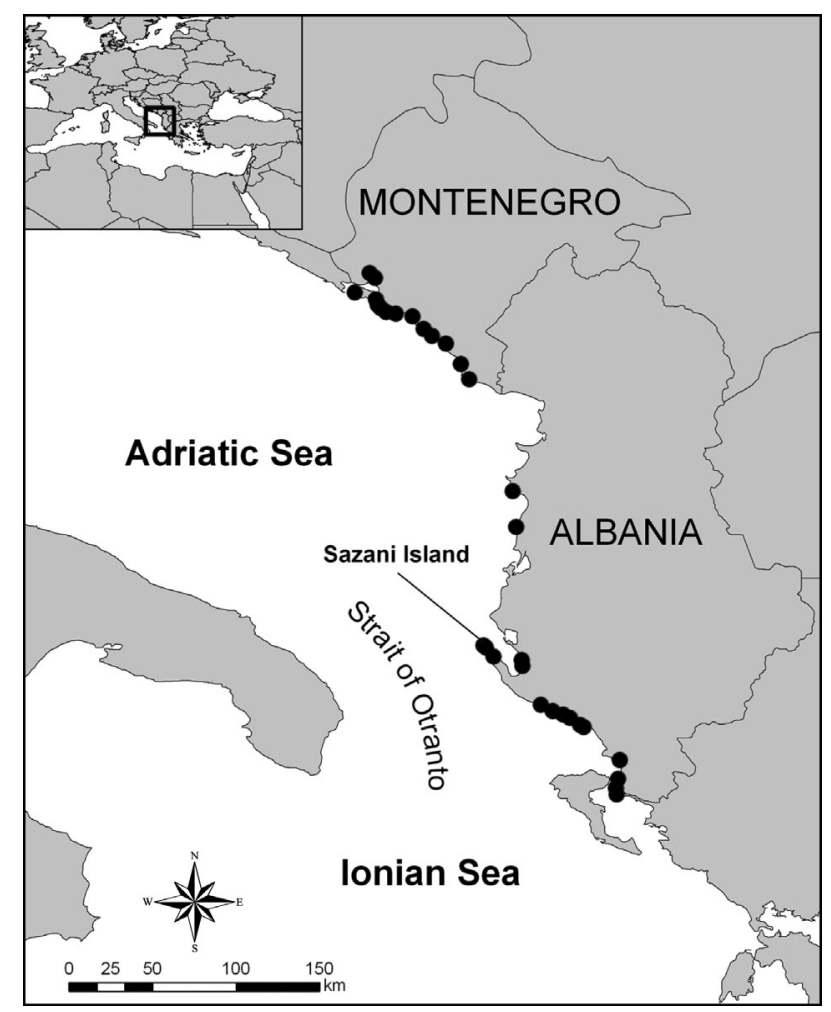

Fig. 1. Study area and sampling sites (dots) 
and substantial freshwater input by the ensemble of Albanian rivers.

Target species. Information on the presence and distribution of marine alien species along the coasts of Albania and Montenegro is scarce and fragmented. Only 12 and 6 alien marine species had been reported in Albania and Montenegro, respectively, before this study (S. Beqiraj, L. Kashta, V. Mačić, A. Zenetos unpubl. data), although many more have been recorded in neighbouring coasts (42 species in Croatia and 60 species in the Greek Ionian coasts) (Zenetos \& Polychronidis 2010, Zenetos et al. 2011). This low number of marine alien records in Albania and Montenegro is partly because of limited research effort in the area.

The target species of the present study were selected because they met all 3 of the following criteria: (1) species previously reported from Albania or Montenegro or from neighboring areas (Greek Ionian and Adriatic coasts), (2) species thriving in the shallow rocky sublittoral zone, and (3) species of a sufficiently large size (or small-sized but forming large-sized colonies) to be visually detectable. Based on these criteria, 13 species were selected as target species (Table 1). For Ganonema farinosum there is no definite evidence of its native or introduced status and it is classified as cryptogenic/ questionable (Zenetos et al. 2010); nevertheless, we included it in our list of target species.

Table 1. Target species of the occupancy survey

\begin{tabular}{|ll|}
\hline Taxon & \multicolumn{1}{c|}{ Species } \\
\hline Plantae & \\
Chlorophyta & $\begin{array}{c}\text { Caulerpa racemosa var. cylindracea } \\
\text { (Sonder) Verlaque, Huisman \& }\end{array}$ \\
& Boudouresque \\
Codium fragile fragile (Suringar) Hariot \\
Rhodophyta & $\begin{array}{c}\text { Asparagopsis taxiformis (Delile) } \\
\text { Trevisan de Saint-Léon }\end{array}$ \\
& Ganonema farinosum (J.V. Lamouroux) \\
& K. C. Fan \& Y. C. Wang \\
& Lophocladia lallemandii (Montagne) \\
Heterokonto- & Stypopodium schimperi (Buchinger ex \\
phyta & Kützing) Verlaque \& Boudouresque \\
Mollusca & \\
Bivalvia & Brachidontes pharaonis (Fischer P., 1870) \\
Gastropoda & Pinctada radiata (Leach, 1814) \\
Aplysia dactylomela Rang, 1828 \\
Crustacea & \\
Decapoda & Percnon gibbesi (H. Milne Edwards, \\
& 1853) \\
Actinopterygii & Fistularia commersonii (Rüppell, 1835) \\
& Siganus luridus (Rüppell, 1829) \\
& Siganus rivulatus Forsskål, 1775 \\
\hline
\end{tabular}

Fieldwork: occupancy estimation and modelling. The field survey in Albania and Montenegro aimed to collect presence/absence data of the target species in order to model occupancy. Species occupancy is defined as the proportion of area, patches or sampling units occupied (or equivalently as the probability of presence in a sampling unit). It is chosen as the appropriate state variable of plant or animal populations in many cases, e.g. in studies of distribution and range (Scott et al. 2002), alien invasions (Hanspach et al. 2008), metapopulation studies (Moilanen 2002), community studies (Martinez-Solano et al. 2003, Weber et al. 2004) and large-scale monitoring (Manley et al. 2004).

The estimation of a population state variable is often confounded by detection probability, i.e. the probability of correctly recording the presence of an individual or species within the area of interest. By detecting a species in a sampling unit, its presence is confirmed with certainty. A non-detection of the species does not imply that the species is genuinely absent from a sampling location. Frequently, a species can be present in an area but go undetected because of random chance. Such 'false absences' lead to incorrect inferences if the imperfect detection of the species is not accounted for; occupancy is underestimated, colonization rates are biased and habitat relationships may well be misleading (Moilanen 2002, MacKenzie et al. 2006).

To address this issue, a set of methods that permit inference about occupancy based on presence/ absence data, while taking into account the imperfect detection of the target species, have been developed (MacKenzie et al. 2006). The goal is to estimate the proportion of sites that are occupied, $\psi$, accepting that the species is not always detected. All methods involve multiple visits to each site, where during the $j$ th visit of a site the target species (given presence) is either detected, with probability $\mathrm{p}_{j}$, or not detected, with probability $\mathrm{q}_{j}=1-\mathrm{p}_{j}$.

For example, consider the detection history $H_{i}=101$ (denoting Site $i$ was surveyed 3 times, with the species being detected in the first and third surveys). The probability of this history would be $\operatorname{Pr}\left(H_{i}=101\right)=\psi p_{1} q_{2} p_{3}$. For sites where the species is never detected there are 2 possibilities, either the species is present but never detected (a 'false absent') or the species is genuinely absent. Thus, $\operatorname{Pr}\left(H_{i}=000\right)=\psi \mathrm{q}_{1} \mathrm{q}_{2} \mathrm{q}_{3}+(1-\psi)$. By deriving such expressions for each of the $\mathrm{N}$ observed detection histories, assuming independent observations, the likelihood of the data will be:

$$
L\left(\psi, \mathbf{p} \mid H_{1}, H_{2}, \ldots, H_{\mathrm{N}}\right)=\prod_{i=1}^{\mathrm{N}} \operatorname{Pr}\left(H_{i}\right)
$$

where $\mathbf{p}$ is the vector of detection probabilities; $\psi$ and $\mathrm{p}_{j}$ can be estimated with standard maximum likelihood techniques (MacKenzie et al. 2006). 
In the present study, $\mathrm{N}=31$ sites were defined in rocky areas along the coastlines of Albania and Montenegro so that they were more or less evenly distributed along the coast, taking into account the restrictions imposed by the geomorphology of the area. At each sampling site, a $200 \mathrm{~m}$ length of coastline was defined with a nylon line deployed with the use of a diving reel. The $200 \mathrm{~m}$ transect was surveyed by snorkelling 3 times by 3 independent observers during standardized 20 min dives. During these surveys, the presence/absence of the selected alien species was recorded by each observer.

For each target species, the potential relationships between the model parameters (occupancy and detection probabilities) and environmental/spatial variables were investigated. Covariates were incorporated by using the logistic model $\theta_{i}=\exp \left(\mathbf{Y}_{i} \boldsymbol{\beta}\right) \cdot\left[1+\exp \left(\mathbf{Y}_{i} \boldsymbol{\beta}\right)\right]^{-1}$, where $\theta_{i}$ is the probability of interest (occupancy or detection probability), $\mathbf{Y}_{i}$ are the covariates to be modelled and $\boldsymbol{\beta}$ is the vector of the covariate coefficients to be estimated (MacKenzie et al. 2006). Standard maximum likelihood techniques were applied to obtain estimates of the model parameters.

Inference was based on the information theory approach (Burnham \& Anderson 2002), i.e. an integrated process of a priori specification of a set of candidate models (based on the science of the problem), model selection based on the principle of parsimony according to Akaike's information criterion (AIC) (Akaike 1973), and the estimation of parameters and their precision. Furthermore, rather than estimating parameters from only the 'best' model, parameters (i.e. occupancy and detection probabilities) were estimated from several or even all the models considered. This multi-model inference has several theoretical and practical advantages (Burnham \& Anderson 2002, Katsanevakis 2006).

The candidate models were selected in order to test the following 3 assumptions for the occupancy of the target species in the study area: (O1) occupancy was constant; (O2) occupancy changed with latitude; and (O3) occupancy depended on mean annual temperature. Two assumptions for detectability were investigated: (D1) detectability was constant across sites and observer independent; and (D2) detectability was constant across sites and observer dependent. Thus, 6 occupancy models were fitted for each target species by combining the 3 assumptions for occupancy with the 2 assumptions for detectability. We did not include both latitude and temperature as covariates in a single model because they were highly correlated, with temperature declining with latitude; such colinearity between covariates could lead to spurious results. Standardized values of latitude and temperature were used as covariates. The software PRESENCE v.3.1 was used to fit the models (Hines 2006).
Mean annual sea surface temperatures (SST) were estimated using nighttime SST data, retrieved from the NASA Physical Oceanography Distributed Active Archive Center and based on the Advanced VeryHigh-Resolution Radiometer (AVHRR) Pathfinder 5 data set between 2000 and 2007 .

$\mathrm{AIC}$ and $\mathrm{AIC}$ differences, $\mathrm{AIC}_{i}=\mathrm{AIC}_{i}-\mathrm{AIC}_{\text {min }}$, were computed over all candidate models. Models with $\Delta \mathrm{AIC}>10$ have essentially no support and might be omitted from further consideration, whereas models with $\triangle \mathrm{AIC}<2$ have substantial support (Burnham \& Anderson 2002). To quantify the plausibility of each model, given the data and set of 6 models, the Akaike weight $w$ of each model was calculated, where $w_{i}=$ $\exp \left(-0.5 \Delta_{i}\right) / \sum_{j} \exp \left(-0.5 \Delta_{j}\right)$. The Akaike weight is considered as the weight of evidence in favour of Model $i$ being the actual best model of the available set of models (Akaike 1983, Burnham \& Anderson 2002). To assess absolute goodness of fit, a Pearson's $\chi^{2}$ statistic was used based on the parametric bootstrap procedure described by MacKenzie \& Bailey (2004). In the case of overdispersion, the variance inflation factor $C$ was estimated from the goodness-of-fit $\chi^{2}$ statistic of the best model between $\psi$ (lat)p(obs) and $\psi$ (temp)p(obs) and its degree of freedom, i.e. $\hat{c}=\chi^{2} / \mathrm{df}$. QAIC, the information criterion for overdispersed data (Burnham \& Anderson 2002), was used instead of AIC for model selection in these cases and the standard errors of the parameter estimates were inflated by $\sqrt{\hat{c}}$ (Burnham \& Anderson 2002, MacKenzie et al. 2006). Estimates of the relative importance of predictor variables $j$ was made by summing the Akaike weights across all the models in the set where each variable occurs $\left[w_{+}(j)\right]$; the larger the sum of Akaike weights, the more important that variable was relative to the other variables (Burnham \& Anderson 2002).

Model averaged estimates of $\psi$ and $\mathrm{p}$ were calculated by the formula:

$$
\hat{\bar{\theta}}=\sum_{i} w_{i} \hat{\theta}_{i}
$$

where $\hat{\bar{\theta}}$ denotes a model averaged estimate of parameter $\theta$ (Burnham \& Anderson 2002). The unconditional standard error of $\theta$ was estimated as:

$$
\operatorname{SE}(\hat{\bar{\theta}})=\sum_{i} w_{i}\left(\operatorname{var}\left(\hat{\theta}_{i} \mid g_{i}\right)+\left(\hat{\theta}_{i}-\hat{\bar{\theta}}\right)^{2}\right)^{1 / 2}
$$

where $\operatorname{var}\left(\hat{\theta}_{i} \mid g_{i}\right)$ is the variance of $\theta$ according to Model $g_{i}$, conditional on the model (Burnham \& Anderson 2002).

Risk assessment. To assess the risk of new alien invaders entering the Adriatic Sea through the Strait of Otranto, we compiled a list of marine alien species not yet reported from the Adriatic Sea that are established in the Central Mediterranean. The borders of the Central Mediterranean are hereby defined as the KythiraAnti-Kythira Strait (Greece) and Libya-Egypt borders 
to the east, Otranto Strait (Italy, Albania) to the north, and Cap Bon (Tunisia) and southwest Sicily to the west, in conformity with Zenetos et al. (2010). The selected species, especially those that are already established along the Greek part of the Ionian Sea, may be considered as the most probable invaders in the south Adriatic in the near future, if they expand their distribution range northwards. Compilation and analyses of data on aliens in the Adriatic, Ionian and central Mediterranean are based on data archived at the Hellenic Centre for Marine Research (HCMR) database for Mediterranean aliens (Zenetos \& Fraggos 2008) updated for January 2011.

\section{RESULTS}

Among the 13 target species, only 6 (Caulerpa racemosa var. cylindracea [hereafter C. racemosa], Asparagopsis taxiformis, Ganonema farinosum, Lophocladia lallemandii, Pinctada radiata and Percnon gibbesi) were found during the survey (Table 2). Records of $G$. farinosum, L. lallemandii, $P$. radiata and $P$. gibbesi from this survey are the first records of these species in Albania. The records of $G$. farinosum and P. gibbesi are also the first records of these species in the Adriatic (see Katsanevakis et al. 2011 for $P$. gibbesi). P. radiata was found alive at only a single site (Saranda) by one observer; another empty shell was found at Ksamil but was not included in the analysis. With only a single record, it was not possible to fit the occupancy models and thus no statistical analysis was conducted for the occupancy of $P$. radiata.

There was no evidence of poor model fit in all cases except for Caulerpa racemosa ( $\chi^{2}$ test, $\mathrm{p}=0.049$ ), for which there was evident overdispersion. Hence, for $C$. racemosa, QAIC was used for model selection, and standard errors were inflated by the estimated variance inflation factor $\hat{c}=2.76$. Among the 5 tested species, the best models supported $\mathrm{O} 3$ in one case (C. racemosa) and $\mathrm{O} 2$ in all other cases (Table 3). However, in most cases none of the assumptions clearly prevail over

Table 2. Detection history of the 6 marine alien species that were observed along the Albanian-Montenegrin coastline in standardized $200 \mathrm{~m}$ transects during September 2010; coordinates show starting points of the transects. The 3 digits in the detection history correspond to the 3 observers; 1 denotes presence and 0 denotes absence; detection histories of 000 omitted for clarity

\begin{tabular}{|c|c|c|c|c|c|c|c|c|c|}
\hline Site & $\begin{array}{l}\text { Latitude } \\
\left({ }^{\circ} \mathrm{N}\right)\end{array}$ & $\begin{array}{l}\text { Longitude } \\
\left({ }^{\circ} \mathrm{E}\right)\end{array}$ & $\begin{array}{c}\text { Mean annual } \\
\text { temperature }\left({ }^{\circ} \mathrm{C}\right)\end{array}$ & $\begin{array}{l}\text { Caulerpa } \\
\text { racemosa }\end{array}$ & $\begin{array}{l}\text { Asparagopsis } \\
\text { taxiformis }\end{array}$ & $\begin{array}{l}\text { Ganonema } \\
\text { farinosum }\end{array}$ & $\begin{array}{l}\text { Lophocladia } \\
\text { lallemandii }\end{array}$ & $\begin{array}{l}\text { Pinctada } \\
\text { radiata }\end{array}$ & $\begin{array}{r}\text { Percnon } \\
\text { gibbesi }\end{array}$ \\
\hline Saranda & 39.8731 & 20.0082 & 19.3 & 111 & & & & 010 & 110 \\
\hline Stillo Cape & 39.6885 & 19.9918 & 20.0 & 100 & & 100 & & & \\
\hline Ftilea Bay & 39.7214 & 19.9874 & 19.8 & 011 & & & & & \\
\hline Ksamil & 39.7712 & 19.9990 & 19.8 & 111 & & 111 & & $\mathrm{a}$ & \\
\hline Qeparo & 40.0517 & 19.8135 & 19.5 & 111 & & & & & \\
\hline Porto Palermo & 40.0627 & 19.7947 & 19.5 & 101 & 100 & & & & 100 \\
\hline Palasa Beach & 40.1709 & 19.5831 & 19.3 & & & & & & \\
\hline Dhermi & 40.1377 & 19.6458 & 19.4 & 100 & 111 & 001 & 111 & & 100 \\
\hline Jali & 40.1183 & 19.7024 & 19.4 & 111 & & 111 & 010 & & \\
\hline Himara Port & 40.1000 & 19.7400 & 19.3 & 100 & & 010 & & & 111 \\
\hline Sazani Island 1 & 40.4912 & 19.2725 & 19.4 & 111 & & & 101 & & \\
\hline Sazani Island 2 & 40.4807 & 19.2871 & 19.3 & 111 & & & & & 110 \\
\hline Shen Jani & 40.4325 & 19.3285 & 19.3 & 101 & & & & & 010 \\
\hline Radhime & 40.3814 & 19.4832 & 19.2 & & & & & & \\
\hline Kala & 40.4130 & 19.4801 & 19.2 & & & & & & \\
\hline Spille & 41.1300 & 19.4498 & 19.3 & & & & & & \\
\hline Curilla & 41.3234 & 19.4306 & 19.2 & 100 & & & & & \\
\hline Kotor-Risan Bay & 42.4999 & 18.6599 & 18.1 & & & & & & \\
\hline Zanjice & 42.3952 & 18.5794 & 19.1 & 101 & & & & & \\
\hline Verige & 42.4750 & 18.6882 & 18.1 & & & & & & \\
\hline Bigova & 42.3577 & 18.6951 & 19.1 & & & & & & \\
\hline Jaz & 42.2815 & 18.8008 & 18.9 & & & & & & \\
\hline Milocer & 42.2667 & 18.8915 & 18.9 & & & & & & \\
\hline Kostovica & 42.2913 & 18.7486 & 19.1 & & & & & & \\
\hline Zli potok & 42.3122 & 18.7197 & 19.1 & & & & & & \\
\hline Zukovica & 42.3287 & 18.7029 & 19.1 & & & & & & \\
\hline Ulcinj & 41.9276 & 19.1974 & 18.8 & & & & & & \\
\hline Utjeha & 42.0100 & 19.1509 & 18.9 & & & & & & \\
\hline Bar & 42.1202 & 19.0712 & 18.9 & & & & & & \\
\hline Canj & 42.1617 & 18.9957 & 19.0 & & & & & & \\
\hline Petrovac & 42.1996 & 18.9511 & 19.1 & & & & & & \\
\hline
\end{tabular}


the other competing assumptions. For Percnon gibbesi, the 2 models assuming $\mathrm{O} 2$ had substantial support $(\Delta \mathrm{AIC}<2)$ and a relative support of $90.4 \%$, whereas all other models had less support. For C. racemosa,

Table 3. Model selection procedure examining factors predicting the probability of presence, $\psi$, of 5 alien species, using simple logistic regression. The factors considered were latitude (lat) and temperature (temp); the model with equal probability of presence for all transects is denoted as $\psi(\cdot)$. Detection probability was considered as either being constant, denoted as $\mathrm{p}(\cdot)$, or different for each of the 3 observers, denoted as $\mathrm{p}$ (obs). Reported is twice the negative log-likelihood $(-21)$, the number of parameters in the model $(K)$, the relative difference in AIC values compared with the top-ranked model ( $\triangle \mathrm{AIC})$, and the AIC model weights $(w)$

\begin{tabular}{|c|c|c|c|c|}
\hline Model & -21 & $K$ & $\Delta \mathrm{AIC}$ & $w(\%)$ \\
\hline \multicolumn{5}{|c|}{ Caulerpa racemosa var. cylindracea ${ }^{\mathrm{a}}$} \\
\hline$\psi($ temp) $\mathrm{p}(\cdot)$ & 69.4 & 3 & 0.0 & 47.2 \\
\hline$\psi($ temp) $\mathrm{p}$ (obs) & 62.7 & 5 & 1.6 & 21.4 \\
\hline$\psi($ lat $) \mathrm{p}(\cdot)$ & 74.2 & 3 & 1.7 & 19.7 \\
\hline$\psi($ lat $) \mathrm{p}(\mathrm{obs})$ & 67.6 & 5 & 3.4 & 8.8 \\
\hline$\psi(\cdot) \mathrm{p}(\cdot)$ & 92.2 & 2 & 6.3 & 2.0 \\
\hline$\psi(\cdot) \mathrm{p}(\mathrm{obs})$ & 85.7 & 4 & 7.9 & 0.9 \\
\hline \multicolumn{5}{|c|}{ Asparagopsis taxiformis } \\
\hline$\psi($ lat $) \mathrm{p}(\cdot)$ & 19.6 & 3 & 0.0 & 33.6 \\
\hline$\psi(\cdot) \mathrm{p}(\cdot)$ & 22.3 & 2 & 0.7 & 23.8 \\
\hline$\psi($ temp) $\mathrm{p}(\cdot)$ & 21.0 & 3 & 1.4 & 16.5 \\
\hline$\psi($ lat) $\mathrm{p}(\mathrm{obs})$ & 17.7 & 5 & 2.1 & 11.9 \\
\hline$\psi(\cdot) \mathrm{p}(\mathrm{obs})$ & 20.4 & 4 & 2.8 & 8.4 \\
\hline ४temp) $\mathrm{p}(\mathrm{obs})$ & 19.1 & 5 & 3.5 & 5.8 \\
\hline \multicolumn{5}{|c|}{ Ganonema farinosum } \\
\hline$\psi($ lat $) \mathrm{p}(\cdot)$ & 35.4 & 3 & 0.0 & 75.2 \\
\hline$\psi($ temp) $\mathrm{p}(\cdot)$ & 39.1 & 3 & 3.6 & 12.2 \\
\hline$\psi($ lat $) \mathrm{p}(\mathrm{obs})$ & 35.4 & 5 & 4.0 & 10.2 \\
\hline$\psi($ temp) $\mathrm{p}$ (obs) & 39.1 & 5 & 7.6 & 1.7 \\
\hline$\psi(\cdot) \mathrm{p}(\cdot)$ & 46.8 & 2 & 9.4 & 0.7 \\
\hline$\psi(\cdot) \mathrm{p}(\mathrm{obs})$ & 46.8 & 4 & 13.4 & 0.1 \\
\hline \multicolumn{5}{|c|}{ Lophocladia lallemandii } \\
\hline$\psi($ lat $) \mathrm{p}(\cdot)$ & 28.1 & 3 & 0.0 & 43.4 \\
\hline$\psi(\cdot) \mathrm{p}(\cdot)$ & 30.9 & 2 & 0.9 & 28.3 \\
\hline$\psi($ temp) $\mathrm{p}(\cdot)$ & 30.0 & 3 & 2.0 & 16.4 \\
\hline$\psi($ lat $) \mathrm{p}(\mathrm{obs})$ & 28.1 & 5 & 4.0 & 5.9 \\
\hline$\psi(\cdot) \mathrm{p}(\mathrm{obs})$ & 30.9 & 4 & 4.9 & 3.8 \\
\hline$\psi($ temp) $\mathrm{p}$ (obs) & 30.0 & 5 & 6.0 & 2.2 \\
\hline \multicolumn{5}{|l|}{ Percnon gibbesi } \\
\hline$\psi($ lat $) \mathrm{p}(\mathrm{obs})$ & 40.5 & 5 & 0.0 & 60.9 \\
\hline$\psi($ lat $) \mathrm{p}(\cdot)$ & 46.0 & 3 & 1.5 & 29.5 \\
\hline$\psi(\cdot) \mathrm{p}(\mathrm{obs})$ & 48.2 & 4 & 5.7 & 3.5 \\
\hline$\psi($ temp) $\mathrm{p}$ (obs) & 46.5 & 5 & 6.0 & 3.1 \\
\hline$\psi(\cdot) \mathrm{p}(\cdot)$ & 53.8 & 2 & 7.3 & 1.6 \\
\hline$\psi($ temp) $\mathrm{p}(\cdot)$ & 52.0 & 3 & 7.5 & 1.4 \\
\hline $\begin{array}{l}{ }^{\mathrm{a}} \text { QAIC used ins } \\
\text { dispersion }\end{array}$ & $\mathrm{AIC}$ & & f evi & t over- \\
\hline
\end{tabular}

although $\mathrm{O} 3$ had greater support $\left[w_{+}(\mathrm{O} 3)=68.6 \%\right]$ than $\mathrm{O} 2\left[w_{+}(\mathrm{O} 2)=28.5 \%\right]$, the latter assumption was also substantially supported by the data; O1 had much less support $\left[w_{+}(\mathrm{O} 1)=2.9 \%\right]$ and was not included in the $95 \%$ confidence set of models. For Ganonema farinosum, although $\mathrm{O} 2$ had more support $\left[w_{+}(\mathrm{O} 2)=\right.$ $85.4 \%]$ than $\mathrm{O} 3\left[w_{+}(\mathrm{O} 3)=13.9 \%\right]$, O3 may not be excluded from further consideration; however, O1 was substantially less supported by the data $\left[w_{+}(\mathrm{O} 1)=\right.$ $0.8 \%$ ] and can be left out. For Asparagopsis taxiformis and Lophocladia lallemandii, no definite conclusion could be reached, as models based on all 3 hypotheses had substantial support by the data $(\triangle \mathrm{AIC}<2)$.

In terms of an overall estimate of occupancy, for the 31 sites surveyed, Caulerpa racemosa had the highest occupancy estimate $(\hat{\Psi}=0.46)$ followed by Percnon gibbesi $(\hat{\Psi}=0.22)$ (Fig. 2). The detection probabilities
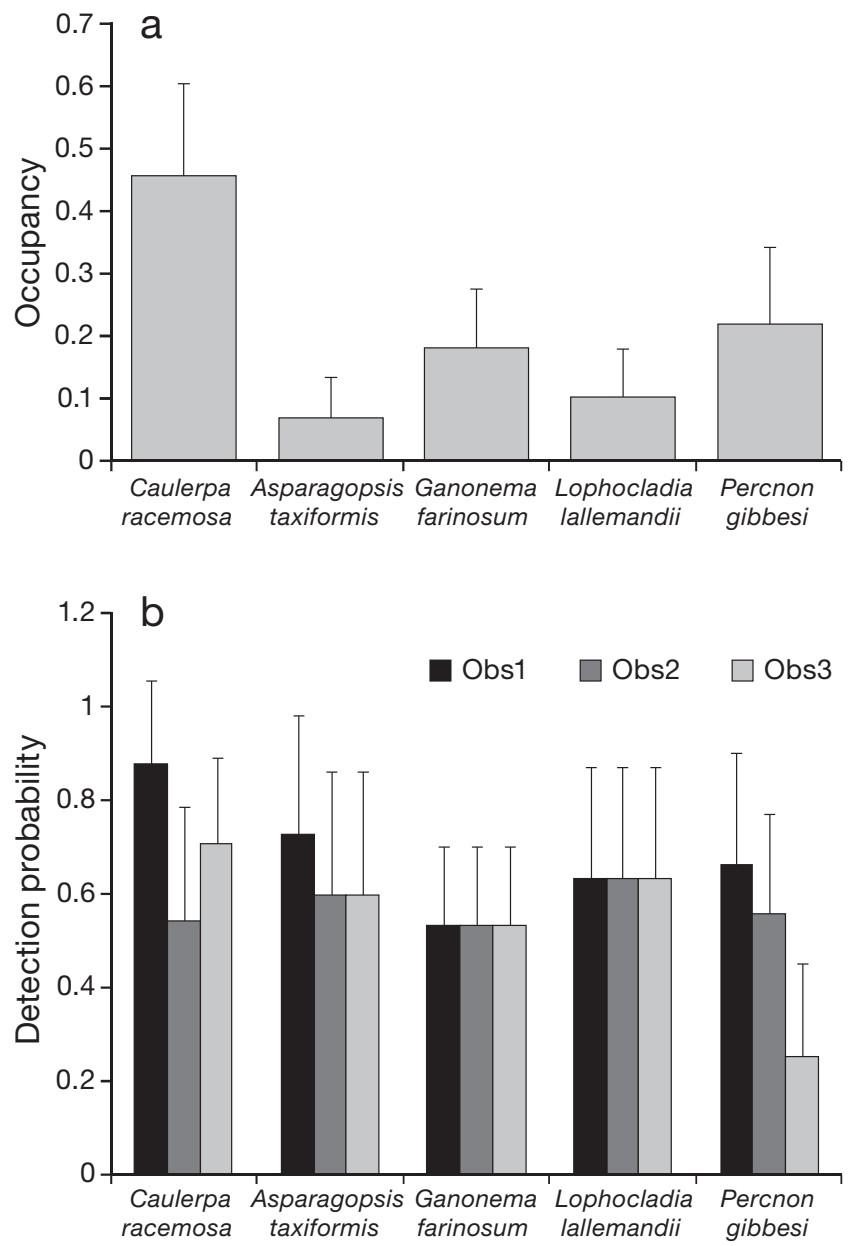

Fig. 2. Parameter estimates (mean $+\mathrm{SE}$ ) for (a) occupancy and (b) detection probability for 5 alien marine species. Modelaveraged parameters are given based on Akaike weights and model selection uncertainty has been taken into account for the estimation of SE. All values are overall estimates for the 31 surveyed sites 
by the 3 observers were $>50 \%$, with the exception of the detection probability of $P$. gibbesi by observer 3, which was $25 \%$ (Fig. 2). The probabilities of false absences (i.e. the probabilities that a species was present at a site but was not detected by any of the 3 observers) were generally low for all 5 species; the highest was $3.1 \%$ for $P$. gibbesi.

The coefficient of latitude was negative in all models assuming $\mathrm{O} 2$ and for all species, indicating a general decline in the occupancy with latitude along the Albanian and Montenegrin coastlines. Analogously, the coefficient of temperature was positive in all models assuming $\mathrm{O} 3$ and for all species, indicating a general decline in the occupancy with decreasing temperature in the case study area. This general decline of occupancy with latitude (or equivalently, the decline of occupancy with decreasing temperature) is depicted in the occupancy maps of the target species in the study area (Fig. 3)

Our investigation revealed that there is a pool of 77 species established in the central Mediterranean but not yet observed in the Adriatic Sea. Among these, 14 species are present in the Greek Ionian Sea (Appendix 1) and may be considered as the most probable newcomers in the Adriatic Sea in the near future. Most of these species are of tropical origin.
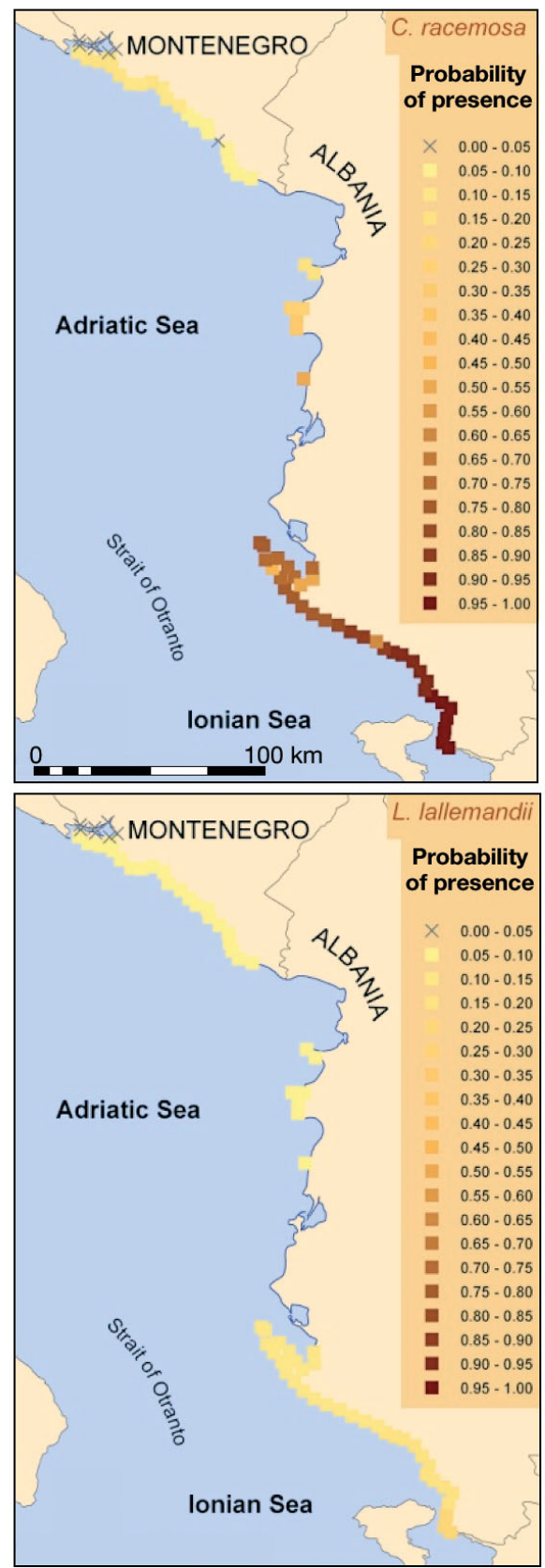

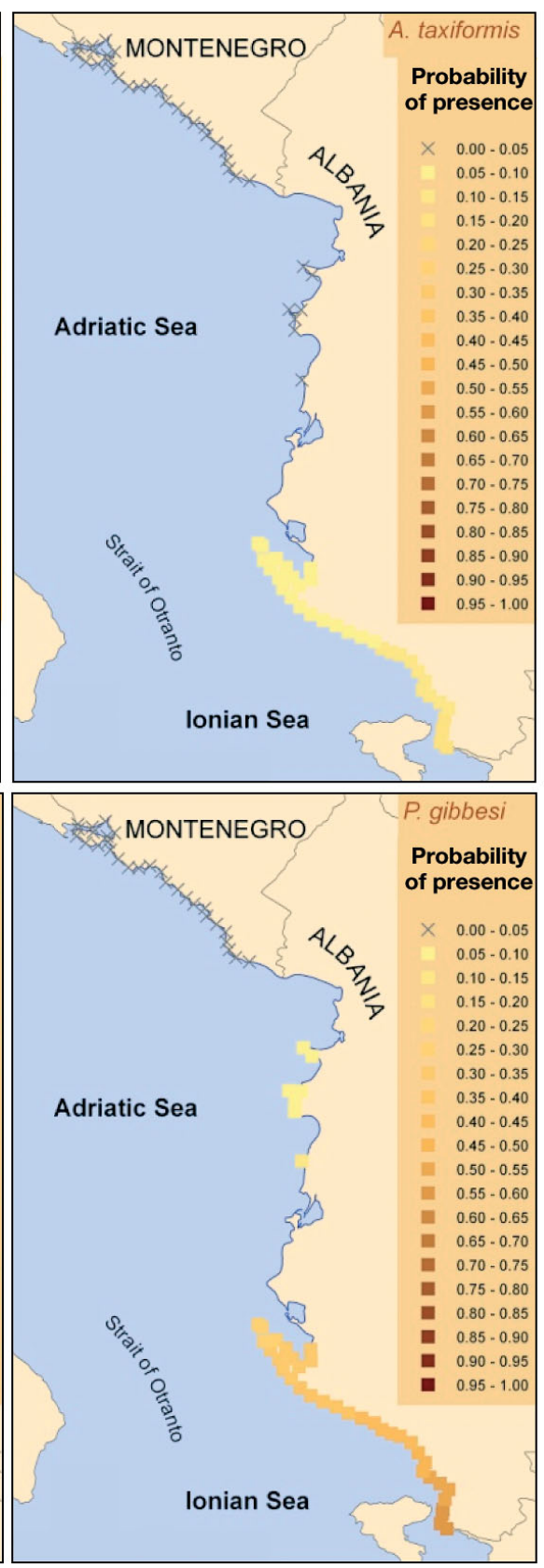

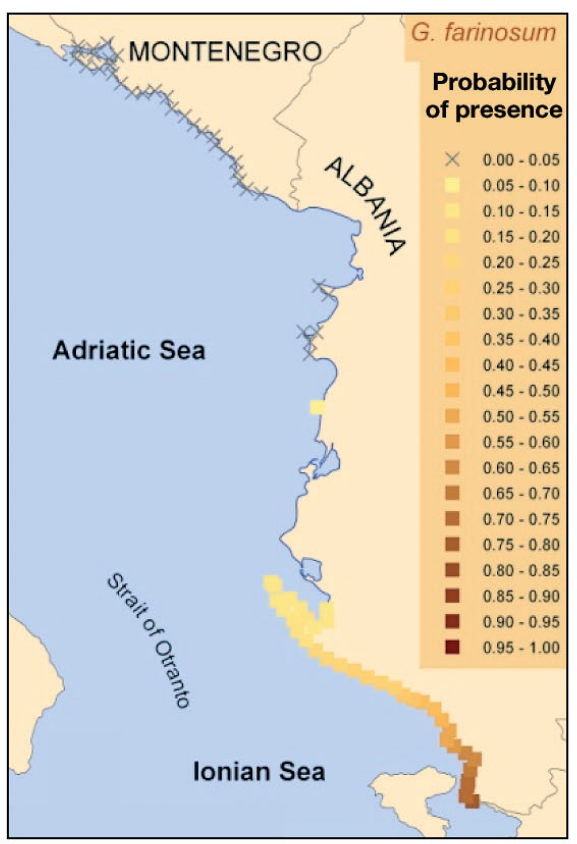

Fig. 3. Occupancy maps of 5 alien marine species along the rocky coastline of Albania and Montenegro. Sandy/ muddy coastlines and wetland areas (mainly in central and northern Albania and southern Montenegro) have been excluded 


\section{DISCUSSION}

Overall, 12 of the 13 target species (except for Codium fragile ssp. fragile) are thermophilic (of tropical or warm temperate origin) and 8 (except for C. fragile ssp. fragile, Caulerpa racemosa, Aplysia dactylomela and Percnon gibbesi) are considered Lessepsian immigrants (i.e. introduced in the Mediterranean through the Suez Canal). This reflects the general status in the Mediterranean, where most of the alien species are thermophilic, originating from the Indo-Pacific, and mainly confined to the littoral and infralittoral zones of the eastern Mediterranean, gradually expanding westwards and northwards mainly by natural dispersal (Zenetos et al. 2010). The current limits of their westward and northward expansion in the Mediterranean largely depend on their lower temperature tolerance and the rising trend in SST, especially since the end of the 1990s (Raitsos et al. 2010). In contrast to the above pattern, A. dactylomela and P. gibbesi were first observed in the central Mediterranean, and C. racemosa in the southern Mediterranean, and then expanded in various directions (Klein \& Verlaque 2008, Yokes 2009, Katsanevakis et al. 2011). However, for all 13 target species of this study, their most probable introduction in the Adriatic Sea is from the Ionian Sea via natural expansion of established populations.

The above statement is supported by the common pattern of spatial distribution across the eastern IonianAdriatic boundary revealed in this study. There was a general pattern of declining occupancy when moving northwards from the northern Ionian Albanian coastal waters towards the southeastern Adriatic for all detected alien species. Had these species been introduced in the Adriatic by shipping, a different occupancy pattern, such as one of high local densities at a high latitude along the eastern coastline and lower or zero densities in the southernmost areas, would be more probable, taking into account the prevailing East Adriatic Current that is directed northwards.

There are 3 plausible explanations (not necessarily excluding each other) for the observed occupancy patterns:

(1) The invasion of some species from the northern Ionian Sea is still in progress and the limit of the current range falls within or near the study area. Lower occupancy and abundance are anticipated near the limits of the range of such species.

(2) The lower temperatures of the Adriatic Sea restrict the northward expansion of thermophilic alien species. The northern limits of the distributions of alien species of tropical or warm temperate origin are mainly defined by temperature regimes. Bianchi (2007) suggested that the February surface isotherms of 15 and $14^{\circ} \mathrm{C}$ can be taken as the 'divides' between warm- and cold-water biota within the Mediterranean basin.
(3) The part of Albania north of the Otranto Strait is characterized by sandy/muddy coasts, large estuarine areas and substantial freshwater input; it is quite possible that the low salinity surface layer and the inappropriate substrate have become a barrier for the northward expansion of some species.

Caulerpa racemosa had the highest occupancy among the target species, confirming its reputation as one of the most aggressive invaders in the Mediterranean (Klein \& Verlaque 2008, Katsanevakis et al. 2010a, Tsiamis et al. 2010). It has been reported from all kinds of substrata with a variety of benthic assemblages, in both polluted and unpolluted areas, and has demonstrated a very high rate of proliferation and high adaptability to physical stressors (Piazzi et al. 2005, Klein \& Verlaque 2008, Katsanevakis et al. 2010a). It has a high potential for dispersal by fragmentation and reestablishment of stolons (Ceccherelli \& Piazzi 2001), formation of propagules (Renoncourt \& Meinesz 2002) and sexual reproduction (Panayotidis \& Žuljevi 2001). Its stolons can quickly elongate and easily overgrow other macroalgal (Piazzi et al. 2001, Piazzi \& Ceccherelli 2006) or invertebrate species (Kruži et al. 2008, Baldacconi \& Corriero 2009). In the Mediterranean Sea, C. racemosa often forms compact monospecific stands, displacing all other algal species (Argyrou et al. 1999, Klein \& Verlaque 2008), contrary to its native habitat in southwestern Australia, where it grows intermixed with other algae (Verlaque et al. 2003).

A bimodal bathymetric distribution of Caulerpa racemosa has been reported in some areas, with higher probabilities of occurrence in very shallow areas $(<4 \mathrm{~m})$ and at depths between 15 and $30 \mathrm{~m}$ (Katsanevakis et al. 2010b); however, it has been reported at depths reaching $70 \mathrm{~m}$ (Klein \& Verlaque 2008). As the present study was restricted to the shallower part of its bathymetric range, it is possible that its estimated occupancy along the Albanian-Montenegrin coastline was underestimated. Because of its high occurrence in the study area and even at northern sites of the eastern Adriatic (Žuljevi et al. 2003, Kruži et al. 2008), its potential for further expansion, and its documented impact on benthic species and ecosystems, C. racemosa should be considered as the most important invasive species along the shallow coastal areas of Albania and Montenegro.

The species with the second highest observed occupancy among the target species was Percnon gibbesi. This species was first observed in the central Mediterranean (Linosa Island, southeastern Sicily and the Balearic Islands) in 1999 and has expanded rapidly since then, invading the entire Mediterranean basin, with the exceptions of its northern reaches such as the central and northern Adriatic Sea, the Ligurian Sea and the northern Aegean Sea (Katsanevakis et al. 
2011). Its further spreading in the Mediterranean basin seems to be primarily the result of natural dispersal via larval transport by currents (Katsanevakis et al. 2011). It is a primarily algivorous crab of the shallow infralittoral rocky shores (usually $<4 \mathrm{~m}$ depth) and may reach densities of 10 ind. $\mathrm{m}^{2}$ (Sciberras \& Schembri 2008, Raineri \& Savini 2010). Its widespread and expanding distribution along the Mediterranean coasts and the high rates of increase in abundance denote a highly invasive species (Katsanevakis et al. 2011). Its present distribution conforms to that of many warmwater species within the Mediterranean (Bianchi et al. 2011) and is consistent with the hypothesis of a further gradual spread northwards from the northeast Ionian Sea, where it is well established and thriving (Katsanevakis et al. 2010c). Our record of $P$. gibbesi at Sazani Island seems to be the northernmost limit of the species distribution in the Ionian-Adriatic basin.

The occupancies of Asparagopsis taxiformis and Lophocladia lallemandii were generally low and the small number of records did not allow the definite selection of one of the 3 candidate hypotheses. It has to be noted that both species have been reported from other northern sites in the Adriatic; A. taxiformis from Croatia, and L. lallemandii from both Croatia and Italy (Zenetos et al. 2010, Verlaque et al. 2011). In contrast, Ganonema farinosum has not been previously reported from the Adriatic; in the present study it was not found north of Dhermi in the Strait of Otranto, which is probably the northernmost limit of its distribution in the Ionian-Adriatic basin. This is consistent with hypothesis $\mathrm{O} 1$ being rejected in favour of $\mathrm{O} 2$ or $\mathrm{O} 3$.

Pinctada radiata is one of the first Lessepsian immigrants in the Mediterranean, as it was first recorded along the coast of northern Egypt just a few years after the opening of the Suez Canal. This thermophilic bivalve is very abundant in the Levantine basin and at some sites can reach densities of many hundreds of individuals per $\mathrm{m}^{2}$, but it is not very common in the Ionian Sea (ELNAIS 2011). Some live specimens, attached to an oil platform transported from the Strait of Sicily to Trieste, were reported in 1996 in Trieste (northern Adriatic), but the species was never recorded again and further surveys in the area confirm that it did not survive (Zenetos et al. 2010). Two juvenile specimens were sighted in 2006 in Croatia (Doğan \& Nerlovic 2008). These incidental records, our single live record from Saranda and the single empty shell found at Ksamil indicate that the species is not yet invasive in the Adriatic. The temperature in the basin seems to be at the tolerance limit of the species.

Of the 171 alien species known in the Adriatic, 90 $(52.6 \%)$ are established, 50 (29.2\%) are casual records and the rest are classified as questionable $(10.5 \%)$ or cryptogenic (7.6\%) (Zenetos et al. 2010). Macrophytes, molluscs and crustaceans are the most numerous invaders, numbering 49, 27 and 24 species, respectively, but the contribution of polychaetes (22) and fish (15) is also significant (Zenetos et al. 2010). The number of established alien species in the southern and middle Adriatic is lower than that in the northern areas of the basin (Zenetos et al. 2010), but it is expected to increase because of the natural expansion of already established species in the central Mediterranean. For the 14 species identified in this study that are already present in the Greek part of the Ionian Sea, there is a high risk of invasion of the southern Adriatic in the near future because of the prevailing surface waters moving northwards along the Albanian and Montenegrin coastline. Most of these species are of tropical affinity and the chances of their establishment in the southern Adriatic will increase if the sea temperature keeps increasing.

It is expected that the impact of alien species will intensify in the future in all Mediterranean regions, including the Adriatic Sea. The present study serves as a tool in the effort to monitor the expansion of alien species in this region and may be utilised as a baseline for future assessments. Further directed effort is needed to assess the rate of occupancy increase of the most invasive aliens and the rate of new introductions, especially in the face of a changing environment.

Acknowledgements. The survey of the Albanian and Montenegrin coastline was conducted in the framework of a trilateral collaboration project (Greece, Albania and Montenegro) funded by UNEP/MAP RAC/SPA (contract nos. 37, 38, 39/ 2010/RAC/SPA). We thank 4 anonymous reviewers and Dr R. Cattaneo-Vietti for their useful comments, which helped us improve the quality of the manuscript.

\section{LITERATURE CITED}

Akaike $H$ (1973) Information theory as an extension of the maximum likelihood principle. In: Petrov BN, Csaki F (eds) Proc 2nd Int Symp Information Theory. Akademiai Kiado, Budapest, p 267-281

Akaike H (1983) Information measures and model selection. Bull Int Stat Inst 44:277-290

Argyrou M, Demetropoulos A, Hadjichristophorou M (1999) Expansion of the macroalga Caulerpa racemosa and changes in soft bottom macrofaunal assemblages in Moni Bay, Cyprus. Oceanol Acta 22:517-528

Artegiani A, Bregant D, Paschini E, Pinardi N, Raicich F, Russo A (1997) The Adriatic Sea general circulation. Part II: Baroclinic circulation structure. J Phys Oceanogr 27:1515-1532

Baldacconi R, Corriero G (2009) Effects of the spread of the alga Caulerpa racemosa var. cylindracea on the sponge assemblage from coralligenous concretions of the Apulian coast (Ionian Sea, Italy). PSZNI: Mar Ecol 30:337-345

Bianchi CN (2007) Biodiversity issues for the forthcoming tropical Mediterranean Sea. Hydrobiologia 580:7-21

Bianchi CN, Morri C (2003) Global sea warming and 'tropicalization' of the Mediterranean Sea: biogeographic and ecological aspects. Biogeographia 24:319-327 
Bianchi CN, Morri C, Chiantore M, Montefalcone M, Parravicini V, Rovere A (2011) Mediterranean Sea biodiversity between the legacy from the past and a future of change. In: Stambler N (ed) Life in the Mediterranean Sea: a look at habitat changes. Nova Science Publishers, New York, in press

Burnham KP, Anderson DR (2002) Model selection and multimodel inference. Springer, Berlin

Ceccherelli G, Piazzi L (2001) Dispersal of Caulerpa racemosa fragments in the Mediterranean: lack of detachment time effect on establishment. Bot Mar 44:209-213

Coll M, Piroddi C, Steenbeek J, Kaschner K and others (2010) The biodiversity of the Mediterranean Sea: estimates, patterns, and threats. PLoS ONE 5:e11842

Doğan A, Nerlovic V (2008) On the occurrence of Pinctada radiata (Mollusca: Bivalvia: Pteriidae), an alien species in Croatian waters. Acta Adriat 49:155-158

ELNAIS (2011) Ellenic network of aquatic invasive species. Available at https://services.ath.hcmr.gr/

Falco P, Griffa A, Poulain PM, Zambianchi E (2000) Transport properties in the Adriatic Sea as deduced from drifter data. J Phys Oceanogr 30:2055-2071

> Hanspach J, Kühn I, Pyšek P, Boos E, Klotz S (2008) Correlates of naturalization and occupancy of introduced ornamentals in Germany. Perspect Plant Ecol 10:241-250

Hines JE (2006) PRESENCE2: software to estimate patch occupancy and related parameters. USGS, Patuxent Wildlife Research Center, Patuxent, MD; available at www.mbr-pwrc.usgs.gov/software/presence.html

Katsanevakis S (2006) Modelling fish growth: model selection, multi-model inference and model selection uncertainty. Fish Res 81:229-235

Katsanevakis S, Issaris Y, Poursanidis D, Thessalou-Legaki M (2010a) Vulnerability of marine habitats to the invasive green alga Caulerpa racemosa var. cylindracea within a marine protected area. Mar Environ Res 70:210-218

Katsanevakis S, Salomidi M, Panou A (2010b) Modelling distribution patterns and habitat preference of the invasive green alga Caulerpa racemosa in the Saronikos Gulf (Eastern Mediterranean). Aquat Biol 10:57-67

Katsanevakis S, Poursanidis D, Issaris Y, Tsiamis K and others (2010c) The invasive crab Percnon gibbesi (H. Milne Edwards, 1853) [Crustacea: Decapoda: Plagusiidae] is spreading in the Aegean and Ionian Seas. Mar Biodivers Rec 3:e53

Katsanevakis S, Poursanidis D, Yokes B, Mačić V and others (2011) Twelve years after the first report of the crab Percnon gibbesi $(\mathrm{H}$. Milne Edwards, 1853) in the Mediterranean: current distribution and invasion rates. J Biol Res (Thessaloniki) 16:224-236

Klein J, Verlaque M (2008) The Caulerpa racemosa invasion: a critical review. Mar Pollut Bull 56:205-225

Kružić P, Žuljević A, Nikolić V (2008) The highly invasive alga Caulerpa racemosa var. cylindracea poses a new threat to the banks of the coral Cladocora caespitosa in the Adriatic Sea. Coral Reefs 27:441

MacKenzie DI, Bailey LL (2004) Assessing the fit of site occupancy models. J Agric Biol Environ Stat 9:300-318

MacKenzie DI, Nichols JD, Royle JA, Pollock KH, Bailey LL, Hines JE (2006) Occupancy estimation and modeling. Academic Press, San Diego, CA

Manca BB, Kovačević V, Gačić M, Viezzoli D (2002) Dense water formation in the southern Adriatic Sea and spreading into the Ionian Sea in the period 1997-1999. J Mar Syst 33-34:133-154

> Manley PN, Zielinski WJ, Schlesinger MD, Mori SR (2004) Evaluation of a multiple-species approach to monitoring species at the ecoregional scale. Ecol Appl 14:296-310

Martinez-Solano I, Bosch J, Garcia-Paris M (2003) Demographic trends and community stability in a montane amphibian assemblage. Conserv Biol 17:238-244

> Moilanen A (2002) Implications of empirical data quality to metapopulation model parameter estimation and application. Oikos 96:516-530

Panayotidis P, Žuljević A (2001) Sexual reproduction of the invasive green alga Caulerpa racemosa var. occidentalis in the Mediterranean Sea. Oceanol Acta 24:199-203

> Piazzi L, Ceccherelli G (2006) Persistence of biological invasion effects: recovery of macroalgal assemblages after removal of Caulerpa racemosa var. cylindracea. Estuar Coast Shelf Sci 68:455-461

Piazzi L, Ceccherelli G, Cinelli F (2001) Threat to macroalgal diversity: effects of the introduced green alga Caulerpa racemosa in the Mediterranean. Mar Ecol Prog Ser 210: 149-159

Piazzi L, Balata D, Ceccherelli G, Cinelli F (2005) Interactive effect of sedimentation and Caulerpa racemosa var. cylindracea invasion on macroalgal assemblages in the Mediterranean Sea. Estuar Coast Shelf Sci 64:467-474

Por FD (2010) Climate optimum rejuvenates the Mediterranean marine world. Integr Zool 5:112-121

Raineri P, Savini D (2010) Percnon gibbesi (H. Milne Edwards, 1853) in Linosa Island 10 years after its first record. Rapp Comm Int Mer Mediterr 39:643

Raitsos DE, Beaugrand G, Georgopoulos D, Zenetos A, Pancucci-Papadopoulou AM, Theocharis A, Papathanassiou E (2010) Global climate change amplifies the entry of tropical species into the eastern Mediterranean Sea. Limnol Oceanogr 55:1478-1484

Renoncourt L, Meinesz A (2002) Formation of propagules on an invasive strain of Caulerpa racemosa (Chlorophyta) in the Mediterranean Sea. Phycologia 41:533-535

> Sciberras M, Schembri PJ (2008) Biology and interspecific interactions of the alien crab Percnon gibbesi in the Maltese Islands. Mar Biol Res 4:321-332

Scott JM, Heglund PJ, Morrison ML, Haufler JB, Raphael MG, Wall WA, Samson FB (2002) Predicting species occurrences. Inland Press, Washington, DC

Tsiamis K, Montesanto B, Panayotidis P, Katsaros C, Verlaque M (2010) Updated records and range expansion of alien marine macrophytes in Greece (2009). Mediterr Mar Sci 11:61-79

Verlaque M, Durand C, Huisman JM, Boudouresque CF, Le Parco Y (2003) On the identity and origin of the Mediterranean invasive Caulerpa racemosa (Caulerpales, Chlorophyta). Eur J Phycol 38:325-339

Verlaque M, Ruitton S, Mineur F, Boudouresque CF (2011) CIESM atlas of exotic species in the Mediterranean. Vol. 4, Macrophytes. CIESM Publishers, Monaco

Weber D, Hinterman U, Zangger A (2004) Scale and trends in species richness: considerations for monitoring biological diversity for political purposes. Glob Ecol Biogeogr 13: 97-104

Yokes MB (2009) Aplysia dactylomela: an alien opisthobranch in the Mediterranean. Mar Biodivers Rec 1:e31

Zenetos A (2009) Marine biological invasions. In: UNEP/MAPPlan Bleu: state of the environment and development in the Mediterranean. UNEP/MAP-Plan Bleu, Athens, p 155-161

Zenetos A (2010) Trend in Aliens species in the Mediterranean. An answer to Galil, 2009 'Taking stock: inventory of alien species in the Mediterranean Sea'. Biol Invasions 12:3379-3381

Zenetos A, Fraggos G (2008) Marine alien species: HCMR data- 
bases for the needs of EEA and UNEP/MAP. Int Conf Mar Data Inform Syst - IMDIS 2008, Athens. Available at http:// hnodc.hcmr.gr/imdis-2008/IMDIS_Presentations/imdis_ POSTERS/Session1/IMG_7444.JPG

Zenetos A, Polychronidis L (2010) Feasibility study in setting up a regional mechanism for collecting, compiling and circulating information on invasive non-indigenous species in the Mediterranean. Contract No 85/RAC/SPA, Report for UNEP/MAP RAC/SPA, Tunis

Zenetos A, Gofas S, Verlaque M, Çinar ME and others (2010)
Alien species in the Mediterranean Sea by 2010. A contribution to the application of European Union's Marine Strategy Framework Directive (MSFD). Part I. Spatial distribution. Mediterr Mar Sci 11:381-493

Zenetos A, Katsanevakis S, Poursanidis D, Crocetta F and others (2011) Marine alien species in Greek seas: additions and amendments by 2010. Mediterr Mar Sci 12:95-120

Žuljević A, Antolić B, Onofri V (2003) First record of Caulerpa racemosa (Caulerpales: Chlorophyta) in the Adriatic Sea. J Mar Biol Assoc UK 83:711-712

Appendix 1. List of potential invading species in the Adriatic Sea. All species that have been established in the central Mediterranean but have not yet been reported in the Adriatic are included in this list; the last column indicates their presence on the Greek Ionian coastline (eastern Ionian Sea)

\begin{tabular}{|c|c|c|c|}
\hline Species & Taxonomic authority & Origin & Greek Ionian \\
\hline \multicolumn{4}{|l|}{ Foraminifera } \\
\hline Amphistegina lessonii & d'Orbigny, 1826 & Circumtropical & - \\
\hline Amphistegina lobifera & Larsen, 1976 & Circumtropical & - \\
\hline Amphistegina madagascariensis & d'Orbigny, 1826 & Indo-Pacific & Present \\
\hline \multicolumn{4}{|l|}{ Macrophyta/Chlorophyta } \\
\hline Caulerpa distichophylla & Sonder & Indo-Pacific & - \\
\hline Caulerpa racemosa var. lamourouxii f. requienii & (Montagne) Weber-van Bosse & Indo-Pacific & Present \\
\hline Codium taylorii & P.C. Silva & Indo-Pacific & - \\
\hline \multicolumn{4}{|l|}{ Macrophyta/Fucophycae } \\
\hline Colpomenia peregrina & Sauvageau & Indo-Pacific & Present \\
\hline Padina boergesenii & Allender \& Kraft & Indo-Pacific & - \\
\hline Padina boryana & Thivy in W.R. Taylor & Indo-Pacific & - \\
\hline Stypopodium schimperi & (Kützing) Verlaque \& Boudouresque & Indo West Pacific & Present \\
\hline \multicolumn{4}{|l|}{ Macrophyta/Rhodophyta } \\
\hline Apoglossum gregarium & (E.Y. Dawson) M.J. Wynne & Pacific & Present \\
\hline Griffithsia corallinoides & (Linnaeus) Trevisan & Atlantic/Pacific & - \\
\hline Hypnea cornuta & (Kützing) J.Agardh & Cosmopolitan & - \\
\hline Laurencia caduciramulosa & Masuda \& Kawaguchi & SW Pacific & Present \\
\hline Plocamium secundatum & (Kützing) Kützing & Tropical/subtropical & - \\
\hline \multicolumn{4}{|l|}{ Polychaeta } \\
\hline Branchiomma boholensis & (Grube, 1878) & Indo-Pacific & - \\
\hline Eunice antennata & (Savigny, 1820) & Indo-Pacific & - \\
\hline Hydroides diramphus & Mörch, 1863 & Circumtropical & Present \\
\hline Linopherus canariensis & Langerhans, 1881 & Atlantic & - \\
\hline Lumbrineris perkinsi & Carrera-Parra, 2001 & Indo-Pacific & - \\
\hline Neanthes agulhana & (Day, 1963) & S Africa & - \\
\hline Pseudonereis anomala & (Gravier, 1900) & Indo-Pacific & Present \\
\hline Syllis hyllebergi & (Licher, 1999) & Red Sea & Present \\
\hline \multicolumn{4}{|l|}{ Crustacea/Amphipoda } \\
\hline Hamimaera hamigera & (Haswell, 1879) & Indo-Pacific & - \\
\hline Stenothoe gallensis & Walker, 1904 & Circumtropical & - \\
\hline \multicolumn{4}{|l|}{ Crustacea/Copepoda } \\
\hline Metacalanus acutioperculum & Ohtsuka, 1984 & Pacific & - \\
\hline \multicolumn{4}{|l|}{ Crustacea/Decapoda } \\
\hline Eucrate crenata & de Haan, 1835 & Indo-Pacific & - \\
\hline Libinia dubia & H. Milne Edwards, 1834 & W Atlantic & - \\
\hline Metapenaeus monoceros & (Fabricius, 1798) & Indo West Pacific & - \\
\hline Metapenaeus stebbingi & (Nobili, 1904) & Indian Ocean & - \\
\hline Necora puber & (Linnaeus, 1767) & NW Atlantic & - \\
\hline Pilumnopeus vauquelini & (Audouin, 1826) & Indian Ocean/Red Sea & - \\
\hline Portunus segnis & (Forsskål, 1775) & Indian Ocean & - \\
\hline Rimapenaeus similis & (Smith, 1885) & W Atlantic & - \\
\hline Trachysalambria palaestinensis & (Steinitz, 1932) & Red Sea & - \\
\hline \multicolumn{4}{|l|}{ Crustacea/Isopoda } \\
\hline Apanthura sandalensis & Stebbing, 1900 & S Africa & - \\
\hline Paradella dianae & (Menzies, 1962) & NE Pacific & - \\
\hline Sphaeroma walkeri & Stebbing, 1905 & Indian Ocean & - \\
\hline
\end{tabular}


Appendix 1. (continued)

\begin{tabular}{|c|c|c|c|}
\hline Species & Taxonomic authority & Origin & areek Ionian \\
\hline \multicolumn{4}{|l|}{ Crustacea/Stomatopoda } \\
\hline Erugosquilla massavensis & (Kossmann, 1880) & Indian Ocean/Red Sea & - \\
\hline \multicolumn{4}{|l|}{ Mollusca/Bivalvia } \\
\hline Fulvia fragilis & (Forsskål, 1775) & Indian & _- \\
\hline Malvufundus regula & (Forsskål, 1775) & Indo-Pacific/Red Sea & - \\
\hline \multicolumn{4}{|l|}{ Mollusca/Gastropoda } \\
\hline Cerithium scabridum & Philippi, 1848 & Indian /Red Sea & - \\
\hline Chelidonura fulvipunctata & Baba, 1938 & Indo-Pacific & - \\
\hline Echinolittorina punctata & (Gmelin, 1791) & Tropical Atlantic & - \\
\hline Erosaria turdus & (Lamarck, 1810) & Indian /Red Sea & - \\
\hline Haminoea cyanomarginata & Heller \& Thompson, 1983 & Red Sea & Present \\
\hline Polycerella emertoni & Verrill, 1881 & Pantropical & Present \\
\hline Syphonota geographica & (Adams \& Reeve, 1850) & Circumtropical & Present \\
\hline \multicolumn{4}{|l|}{ Chordata/Ascidiacea } \\
\hline Distaplia bermudensis & Van Name, 1902 & W Atlantic & - \\
\hline Ecteinascidia styeloides & (Traustedt, 1882) & Circumtropical & - \\
\hline Microcosmus exasperatus & Heller, 1878 & Indo-Pacific & - \\
\hline Microcosmus squamiger & Hartmeyer \& Michaelsen, 1928 & Circumtropical & - \\
\hline Polyandrocarpa zorritensis & (Van Name, 1931) & E Pacific & - \\
\hline \multicolumn{4}{|l|}{ Echinodermata } \\
\hline Eucidaris tribuloides & (Lamarck, 1816) & (sub)Tropical Atlantic & - \\
\hline Ophiactis savignyi & (Müller \& Troschel, 1842) & Circumtropical & - \\
\hline \multicolumn{4}{|l|}{ Fish/Actinopterygii } \\
\hline Atherinomorus forskalii & (Rüppell, 1838) & Tropical Atlantic & - \\
\hline Beryx splendens & Lowe, 1834 & Circumtropical & - \\
\hline Cephalopholis taeniops & (Valeciennes, 1828) & Subtropical Atlantic & - \\
\hline Crenidens crenidens & (Forsskål, 1775) & Indian Ocean & - \\
\hline Etrumeus teres & (DeKay, 1848) & Subtropical & - \\
\hline Microchirus hexophthalmus & (Bennet, 1831) & Tropical Atlantic & - \\
\hline Pempheris vanicolensis & Cuvier, 1831 & Indo-Pacific & - \\
\hline Pisodonophis semicinctus & (Richardson, 1848) & Tropical Atlantic & - \\
\hline Scomberomorus commerson & Lacepède, 1800 & Indo-Pacific & - \\
\hline Seriola carpenteri & Mather, 1971 & Tropical Atlantic & - \\
\hline Seriola fasciata & (Bloch, 1793) & Tropical Atlantic & Present \\
\hline Sphyraena flavicauda & Rüppell, 1838 & Indian Ocean & - \\
\hline Synaptura lusitanica & Capello, 1868) & Tropical Atlantic & - \\
\hline Trachyscorpia cristulata echinata & (Koehler, 1869) & Tropical Atlantic & - \\
\hline Upeneus moluccensis & (Bleeker, 1855) & Indo-Pacific & Present \\
\hline Upeneus pori & Ben-Tuvia \& Golani, 1989 & Indian Ocean & - \\
\hline
\end{tabular}

Editorial responsibility: Riccardo Cattaneo-Vietti, Genova, Italy
Submitted: February 25, 2011; Accepted: May 20, 2011

Proofs received from author(s): July 31, 2011 